\title{
The Theological Importance Of Creation In The Old Testament*
}

\author{
Introduction
}

The Bible begins with a story about the creation of the world by God. The exegesis of the Old Testament usually begins with an explanation of the story of the Book of Genesis about the beginning of the world. This story, considered to be the work of a priestly author, is characterised by a certain schematic and at the same time lofty idea of God's transcendence. The author wants to give the foundations of strict monotheism, which is the cornerstone of the Israeli religion. It depicts an extra-worldly being, called Elohim, who exists before, above and beyond all things and which at some point called the world into existence. The author of the story treats only about the creation of the visible world, describing the works of creation from the least perfect to the most complicated, of course according to his own judgement. Based on the Bible, it is not surprising that faith in God, the Creator of heaven and earth, appears to many people today as the fundamental truth of Christian teaching. To believe means to recognise that the world was created by God.

Exegeses of the Old Testament have long ago stated that the God of Israel revealed Himself to his people first and foremost as the Saviour. Before he revealed himself as the Creator of the universe, he intervened in the history of the nation in order to free it from the shackles of Egypt. For the people of the Old Testament, Yahweh is above all and indeed the Saviour God ${ }^{1}$. Faith in the Creator God takes a secondary place in the Old Testament in relation to faith

STV 26(1988)1.

1 Cf. P. Humbert, bara, “Theologische Zeitschrift” 3 (1947), 401; Qana, Festschrift f. A. Bertholet (1950), 259ff; Padl, ZAW 24 (1953), 35ff; yasar (BZAW 77), Giessen 1958, 82ff. It is characteristic that M. Garcia Cordero, Creazione (Racconto della Genesi sulla), in: Enciclopedia della Biblia II, Tanino, col. 603, believes that the Hebrew verb bara in its original sense does 
in the Saviour God. The primary and direct object of the Israeli faith is God, who brought the nation out of Egyptian captivity, and not the God who created heaven and earth ${ }^{2}$. The Old Testament scriptures show that the statement "I am your Saviour" called for centuries another statement, "I am your Creator." The theme of creation is a constitutive part of soteriology, i.e. the science of salvation. The very faith in Yahweh as Creator is relatively late. First Israel knew Yahweh as its God, and only through experience in the history of salvation did it come to the knowledge that Yahweh is the Creator God and Lord not only of Israel, but of the whole world. The theology of creation, the fruit of which is Genesis 1:1-2.4a, was developed only in the Babylonian captivity. This will be particularly evident in Deutero-Isaiah, in whom the terms "God" and "Creator" will be used interchangeably, as terms describing the same reality of the omnipotent God". Thus, the theme of the Creator God is secondary to the theme of the Saviour God and as such it appears quite late in the history of Israeli traditions, being subordinated to the theme of salvation history ${ }^{5}$.

\section{The Oldest Period}

During a long period of time, which lasted many centuries, Israel knew the cosmogenic tradition, but did not give it any particular theological significance. Creation is not an integral part of the original credo of Israel. It is a generally

not actually mean "to create," but "to free" or "to set free," only the context in which the verb occurs leads to the idea of creation.

2 E. Jacob, Théologie de l'Ancient Testament, Neuchâtel 1955, 110.

3 W. Vischer, Quand et porquoi Dieu a-t il révélé à Israëlqu'il est le Dieu créateur?, "Foi et Vie" 58(1959)3-4, 3ff. Cf. G. von Rad, Das theologische Problem des alttestamentlischen Schöpfungsglaubens, BZAW 66 (1036), 38ff; Idem, Theologie des Alten Testaments (I), München 1966, 149ff.359ff; Theologie des Alten Testaments (II), München 1968, $248 \mathrm{ff} .357 \mathrm{ff} ;$ G. Lambert, La création dans la Bible, NRTh 75 (1953), 252-281; B.D. Napier, On Creation Faith in the Old Testament, "Interpr." 16 (1962), 21-42; Th. Boman, The Biblieal Doctrine of Creation, "The Church Quarterly Review" 165 (1064), 140-151; K. Barth, Die Kirchliche Dogmatik III/1, München 1945.

4 M. Filipiak, Biblia o człowieku. Zarys antropologii biblijnej Starego Testamentu, Lublin 1974, 73, note 1; see B. Couroyer, Isaïe 40,12, RB 73 (1966), 186-196; see also R. Koch, Teologia della redenzione in Genesi 1 - 11, Rome 1967.

5 Cf. Ch. Hauret, Origines de l'univers et de l'homme d'après la Bible, DBS VI (1960), col. 908-926. "Es ist aber schwerlich zu übersehen, dass in der Aussage des ATs die in der Mitte der Geschichte geschobene “Herausführung Israels aus Ägyten” der priamäre Orientierungspunkt ist." W. Zimmerli, Grundriss der alttestamentlichen Theologie (Theologische Wissenschaft 3), Stuttgart-Berlin-Köln-Mainz 1972, 25. 
accepted truth that exists in different peoples, regardless of their intellectual level and cultural level ${ }^{6}$. The nations neighbouring Israel (Sumerians, Babylonians and Egyptians) had a tradition of creation, or better, of the origin and organisation of the world, although they practically knew no creation. Stories of a religious nature convey faith in the existence of matter from which gods were born? ${ }^{7}$.

It is under the influence of political and religious events that Israel becomes aware of the theological significance of the problem of the world's emergence. Israel's neighbours have been interested in this for a long time, as evidenced by the cosmogonic systems developed by Egyptian priests in Heliopolis, Memphis and Hierapolis, or the Sumerian-Acadian traditions led by the famous Babylonian epic Enûma Elišs, composed in honour of the god Marduk for New Year's Day ${ }^{8}$.

Data on the origins of the world are less visible in Ugarit and Canaan, although Baal's fight with the god of the sea (Jam) could be a reflection of the myth of creation. In particular, the god El, well known in the Semitic world, is praised in Ugarit as the father of humanity, the creator of visible things, and in other documents as the great-grand maker of the earth'. The God El also appears in the Old Testament in the patriarchal tradition that tells of Abraham's meeting with Melchizedek, priest of El-Ejon, Creator of Heaven and Earth (Genesis 14:18ff). This means that Israel knew the notion of creation before it had drawn consequences on a theological level.

\section{The Jahwist Tradition}

Jahwist was the first to capture the importance of this topic. He begins his work with a story about the formation of a man and a woman by Yahweh and their being placed in the garden of Eden (Genesis 2). However, this story serves as an introduction to Genesis 3 because it allows the author to place the persons of the drama (Yahweh, Adam, Eve and the serpent) to lead the Jahwist theme through episodes such as the murder of Abel, the Flood, the Tower of Babel to the choice of Abraham through the story of the patriarchs and their descendants (Genesis 12-14). The cosmogonic motif is doubly limited: Jahwist mentions the appearance of animals and the first human couple in the oasis that God \#prepared for them

6 Cf. Deuteronomy 26:5ff; Joshua 24:2ff; for the tradition E the theme of creation is unknown, not much space is devoted to it in tradition $\mathrm{D}$.

7 Cf. M. Gołębiewski, Biblia a literatury Wschodu, AK 441 (1982), 219-233.

8 R. Labat, A. Caquot, Les religions du Proche-Orient asiatique, 1970.

$9 \quad$ J. Gray, The Legacy of Canaan, VTSup 5 (1963), 154ff. 
on the steppes, as opposed to Genesis 1, where the perspective is directed towards the whole cosmos. Moreover, the story from Genesis 2 acquires meaning only in the perspective of the history of salvation. The creation of man leads to the election of Abraham and, as such, is the first chapter in the history of God's blessings, followed by Jahwist's theology covering the period from the ancestor of Israel to all mankind ${ }^{10}$.

To understand the meaning of the story of the beginning, told by the Jahwist in Genesis 2-4, one has to realise that he lives in the $10^{\text {th }}$ century, after the glorious reign of David. He was closely aware of the changes caused by the royal conquests. Jahwist tries to interpret the events of his time by combining them with the patriarchal tradition. He wants to show David's reign on the line of Yahweh's plans ${ }^{11}$. For the first time in its history, Israel is confronted as a political power with other nations. His political role is to be justified from a theological point of view. Therefore, the Jahwist is not satisfied with the reference to the epoch of the fathers, but returns to the beginning of human history, so that in the name of faith the place of Israel among other nations may be confirmed. In this way it is possible to explain the fact why the Jahwist's description at the beginning takes up the subject of creation.

There is a widespread view that Genesis 2:4b-25 is the second description of the creation of the world. This is justified by the fact that the text refers to the creation of the first man and his wife, and then to the creation of animals and trees. It is also possible to point out some parallels of description to the Genesis 1 creation, in which some of the statements are theoretical and dogmatic in nature, while here they are rather pictorial and concrete in nature. This fragment is not an independent whole, but rather a preparation preceding the description of the fall of man and is connected with this description by the unity of the narrative form and subject matter. In addition to a small mention in the introduction to the story (in $5 \mathrm{n}$ ), which has a negative character, there is not a single word about the creation of great cosmic spaces and other works. All the attention is focused on the question of how these things exist, what kind of mutual, concrete relations bind them, what the world looks like from the point of view of good and evil ${ }^{12}$.

10 Cf. G. von Rad, Das erste Buch Mose Genesis. Kapitel 1-12, 9 (ATD 2), Göttingen *1972, 27-42; cf. also H.W. Wolff, Das Ke- rygma des Jahwisten, EwTh 24 (1964), 73-98 (Ges. St. 1964, 345ff).

11 R. Clements, Abraham and David. Genesis 15 and its Meaning for Israelite Tradition (SBT II), 5, 1967.

12 W. Trilling, Stworzenie i upadek, Warsaw 1980, $12 \mathrm{ff}$. 


\section{Deutero-Isaiah Theology}

In Deutero-Isaiah cosmogony takes on paramount importance due to the circumstances in which Israel finds itself in the Prophet's age ${ }^{13}$. The elite of the chosen people live in bondage, and the fall of Jerusalem in 587 completely buried any hope of a renewal of the Judeans. Meanwhile, an anonymous prophet, called Deutero-Isaiah, sees a radical change in the situation of exiles in the first military successes of Cyrus (around 545-540), who will become the ruler of Babylon in the year 538. On behalf of Yahweh he announces the future release of the Jewish community in Mesopotamia, its return to the Holy Land and the restoration of worship in Jerusalem ${ }^{14}$.

This message of consolation was badly received by contemporaries who doubted that Yahweh would and could intervene in favour of the chosen people. Did the fall of Judah not show her weakness? Could God, who does not have his own sanctuary, compete with Marduk, whose power extends beyond the borders of Babylon?

The Prophet responds to opponents' allegations, referring to the creation of the world by the God of Israel. He constantly returns to this point in his oracles $^{15}$. Yahweh is able to gather the nation around him because he directs the events of history, gives orders to heavenly bodies, princes and elements of the world. His power over history and nature, which no one can question, comes from the fact that he created heaven and earth without anyone's help. He himself is the ruler of the world because he is the only Creator of the world; he holds everything in his hands: Cyrus and Babylonia, Judaeans, past and future. The motif of the Creator God in Deutero-Isaiah is not to praise Yahweh (although this intention is not alien to the prophet $)^{16}$, but rather to strengthen the present and future fate of the nation. Thus creation in Deutero-Isaiah has a soteriological function (Is 42, 5; 45, 6n. 18 and other). The exile prophet establishes a close relationship between salvation and creation. He does not limit himself

13 R. Rendorff, Die theologische Stellung des Schöpfungsglaubens bei Deutero-Jesaja, ZThK 51 (1954), 3-13.

14 Cf. R. Martin-Achard, Israel et nations, CTh 42 (1959), $13 \mathrm{ff}$.

15 Cf. Is 40-42, esp. 40, 12ff; 44, 24ff; 45, $12 \mathrm{ff}$.

${ }^{16}{ }^{16}$ G. von Rad, Theologie (II), 245. "Créer et racheter sont pratiquement synonymes chez le Second Esaïe qui parle aussi de la création d'Israël pour rappeler que celui-ci est le peuple élu - Es 43, 1, 7, 15; 44, 24 etc.” R. Martin-Achard, Remarques sur la signification théologique de la création selon l'Ancient Testament, in: Permanence de l'Ancient Testament. Recherches d'exégèse et de théologie, "Cahiers de la Revue de Théologie et de Philosophie 14", Genève-Lausanne-Neuchâtel 1964, 150. 
only to juxtaposing them, but also makes them one and the same reality. In his opinion, the victory of Yahweh over the forces of chaos is a harbinger of his triumph over Babylon, and the choice of Israel and his return to Jerusalem are in fact creative works. The Creation is the first of Yahweh's historical wonders and testifies in its own way to God's saving will ${ }^{17}$.

The theme of creation appears in Deutero-Isaiah in the prologue (40) and in the epilogue of his book (55). It takes the form of all possible literary genres used by our prophet. These statements play a supportive and encouraging role in the prophet's argumentation. If Yahweh is the Creator not only of Israel, but also of the world, He is also the Lord of the universe, and as such He has the Babylonians in His hands. He can also grant a new grace to a nation that is in captivity and distance the violence of its enemies. The following texts come into play here: 40:12-31; 43:1-7; 44:24-28 (-45:8); 54:4-6 and others.

Statements about creation in Deutero-Isaiah have above all a tendency and a polemic function: if Yahweh is the Creator of the universe and his Lord, it is not the Babylonian god Marduk. By this statement, the author wants to inspire trust and confidence in the salvific work of Yahweh. These statements are subordinated to the Deutero-Isaian understanding of history and as such are an expression of the author's salvific faith. In first place is the historical choice of Israel as the greatest creative act, which is only the work of God's grace. In this way, concepts such as creation and the new way out can occur together, as the first way out was also the creation of Israel (cf. 51:9-13 and 42:5; 43:2.19; 44:24; $45: 6-8 ; 48: 3.7)$. The new work of salvation of Yahweh is also a new creation. The liberation of Israel - understood as a creature - is rooted in the will of Yahweh and finds its basis there. Therefore, in the Deutero-Isaiah creation and history, history and nature are not yet radically separated, as has been the case in theology until our times ${ }^{18}$.

Expressions that the author uses to define the actions of the creation are interchangeable with expressions that are historically coloured, namely, the verb "choose." Thus creation and history create unity for him. The new salvation will be a new creature (40:3; 40:28-31; 46:9f; 48:12f) that is more than a return to the old order. In this way the theology of creation and eschatology are closely connected. Thus, statements about creation take on an existential dimension

17 G. von Rad, Theologie (II): “...die Schöpfung ist ihm das erste der geschichtlichen Wunder Jahwes und ein sonderliches Zeugnis seines Heilswillens.”

18 Cf. Th.M. Ludwig, The Tradition of Establishing of the Earth in Deutero-Isaiah, JBL 92 (1973), 345-357. 
in Deutero-Isaiah; they are simply directed towards the present. It is about awakening listeners to believe that God is in charge of the events of history.

Particularly noteworthy are his statements about the creative power of the word Yahweh (cf. Is 40:6.8; 55:8-11 and 44:26; 45:23f; 51:16). The prophet's reflection on this subject grows to the rank of a synthesis ${ }^{19}$. It can be said that the central point of the prophet's proclamation is the creative aspect of Israel's redemption. By introducing the term "goel" applied to Yahweh and the theme of being chosen, Deutero-Isaiah gives the reason why Yahweh intervened creatively to redeem Israel ${ }^{20}$. Through his preaching, he also opposes the extremely attractive power of worship of Marduk and the deities associated with him in Babylonia, with magnificent feasts and rites, with priests, countless wise men and fortune-tellers. The theme of creation, which underpins the salvation of Israel, serves at the same time to worship the Yahweh and devalue the power usurped by the pagan gods. The prophet's declarations therefore contain a doxological and polemic aspect, which should not be forgotten when analysing the writings of Deutero-Isaiah.

\section{Priestly Tradition (Genesis 1)}

In Genesis 1, the cosmological theme receives its fullest expression. However, the impressive character of the first page of the Bible cannot overshadow other manifestations of faith in the Creator God. Despite its importance and rank, the priestly story cannot be privileged among other statements of the Old Testament on this subject ${ }^{21}$.

Genesis 1 is both doctrinal and sacred in character; it combines scientific interest with liturgical care. A story composed in a priestly environment - and perhaps recited for a liturgical ceremony - strikes us with its weight, rhythm and extremely solemn tone. The author tries - in the Egyptian wise man's way to enumerate all the components of the cosmos, allocating to each element the appropriate place that has been set for him in God's plan. This concerns light, darkness, water, sky, earth, plants, animals, and so on. The author writes simply for the glory of God. Vocabulary, style, composition, content - everything

19 Cf. H.D. Preuss, Deuterojesaja. Eine Einführung in seine Botschaft, Neukirchen 1976, $58-60$

20 C. Stuhkmueller, Creative Redemption in Deutero-Isaiah (AnBib 43), Rome 1970, 233-237.

21 W.H. Schmidt, Die Schöpfungsgeschichte der Priester Schrift (WMANT 17), Neukirchen 1964 d P. Beauchamp, Création et séparation. Étude exégétique du (...) Gen 1, Paris 1970. 
is aimed at expressing the greatness, wisdom and goodness of a creative work. From beginning to end, the story praises the creator of heaven and earth.

This doxological intention occurs together with the polemic finale. Genesis 1 definitely excludes the existence of any divine reality other than the Creator. It desacralises radically the world and everything it contains: the forces of chaos are given for the service of God's word, the earth is obedient to Him, the heavenly bodies serve as day and night markers, there is nothing divine in the universe. Heaven and earth are creations and as such depend on the will of God who created them.

Against the background of the cosmogony and beliefs of Israel's neighbours, Hexameron is characterised by exceptional, if not surprising, theological sobriety. There is no trace of faith in the multitude of conflicting deities, which, according to the Mesopotamian myth, originated from the waters of primordial chaos. The world came into being not as a result of a struggle between the demiurge and other gods, nor by another birth among gods, but it is the work of the powerful God, which exists before and aside of which no god exists and will exist (cf. Is 43:10; 45:5). Hexameron shows celestial bodies, like the sun, moon and stars as entities completely natural and subordinated to the transcendent God, they are simply ordinary creatures ${ }^{22}$.

This profanation of the cosmos, which contrasts with the way we look at the nature of the nations neighbouring Israel, allows mankind to live without the eternal fear of confronting enemy forces. It is a liberating description because it frees man from the cult of natural powers, gives the world to man, while in other cosmogonies man is a slave of the world. Genesis 1 places man over creation and entrusts him with the mission of representing the Creator, and to what extent man is the image of God and his icon. The author shows man as the most perfect of God's creations. For he has something in him of God himself, he is his image, which manifests itself in the fact that, by the will of the Creator, he conquers the earth and rules over other living beings. In a woman she sees a biblical creature equal to a man. Sexual intercourse and progeny is presented in Hexameron as the realisation of the will of the Creator.

According to Genesis 1, God establishes an order that determines the fate of the cosmos and man. The latter is determined by space and time, and is given a rhythm of life. In order to better grasp the theological intention of Genesis 1, it is necessary to mention the circumstances in which this chapter was written. For a priestly writer, the conquest of Jerusalem by Nebuchadnezzar meant that 
the Israeli tradition, which the nation had lived through the centuries, was completely challenged. The author's aim is to rethink the whole history of Israel and to base its existence on fundamentals so permanent that the crisis marked by the fall of the kingdom of Judah can no longer be repeated.

God's creative action is purposeful and reasonable. The clear construction of the description of the creature is supposed to give the impression of a deliberate and planned order. The Creator is wise, is the God of order and harmony. This kind of image of God is the outflow of contemplative wisdom into the magnificence of the world. This wisdom is based on Israel's experience to date, such as the creative power of words, the superiority of the Yahweh over all nations and their gods, the one-of-a-kind grace for man, and the ordering power of the Law ${ }^{23}$.

The life of the chosen people can be safeguarded if it is based on certain and definite institutions, perpetuated by God forever. Genesis 1 tells us about the foundation of the first of these dispositions. It is the establishment of the order of creation, which will be confirmed by the Noachite covenant (Genesis 9), while Genesis 17 designates a place for the people of Yahweh within the framework of mankind according to the order of Abraham. If the Jahwist, through his story of the appearance of Adam and Eve, opens his story of salvation, the priestly writer begins the story of divine institutions that place the world, humanity and the nation of Israel in mutual relations by referring to the creation of the heavens and the earth. Fidelity to God in relation to what he decided "at the beginning" is the surest guarantee of the future of Jerusalem and the nations.

The fact that it was at the time of the greatest humiliation that such lofty thoughts could be formulated, especially about man, is a clear sign of unbreakable faith, but also of the fact that Israel opened itself at that time to the wisdom of the world around it and was thus able to grasp the image of man in a more universal way. The Book of Genesis does not only refer to man as a member of the Israeli nation, to whom God speaks and to whom He sometimes severely punishes, but to man in general, as a thinker or philosopher can talk about it ${ }^{24}$.

24 Ibid. 


\section{Theology Of Psaltery Hymns}

One might think that in Israeli hymnology there are numerous doxological statements referring to the Creator God. In fact, the psalmists mention the saving interventions of Yahweh at the time of departure and in relation to Zion, they speak of the royal reign of the Yahweh and His goodness in relation to the unhappy, they praise the care and justice of God. Meanwhile, faith in the God "who created heaven and earth" is expressed in the Psalter only in passing, generally in relation to the history of salvation, and in prayers from a fairly late period. Thus, the theme of creation in its current form, Ps 19, combines and is subordinated to the theme of the sublimity of the Law, which was given to the chosen people ${ }^{25}$. In Ps 136, on the other hand, this theme is directly related to the saving interventions of Yahweh at the time of leaving Egypt and is shown on an equal footing under the sign of merciful fidelity to $\operatorname{God}^{26}$.

Due to the representativeness of this psalm, it is appropriate to deal with it somewhat more broadly. While Psalm 104 is dedicated solely to creation and makes no reference to Israel, in Psalm 136 the first verses are a hymn of praise to creation, and two thirds of the psalm are dedicated to praise Israel, who glorifies his God for the great works done in history. These are two great events: the liberation of Israel and the creation of the universe. This close-up of the two themes is extremely characteristic because it contains a specific concept of the history of Israel and the creation of the world. The Psalm has a very clear structure. After the worship of Jehovah, "God over gods" and "Lord over lords" (in 1-3) worships the Creator God (in 4-9), showing His strange action in honour of Israel (in 10-24). Israel begins by worshipping the creation of the universe in order to reach its own history with the same refrain. God created the world and took care of His people in the same way and for the same reason, "for His mercy forever." A direct transition from creation to "the moon and the stars to rule at night" (in 9) to the fact that God "beat the first-borns of Egyptians" (in 10) is not accidental at all. Thus, starting from the creation of the universe, we are reminded of the main outlines of the history of Israel: the escape from Egypt, the humiliation of enemies, the passage through the Red Sea to the desert and the entrance to the Promised Land.

25 Ps 19 consists of two pieces originally independent of each other, the first of which seems to be older. Cf. H.J. Kraus, Psalmen 1 (BK XV/3), Neukardhen 1966, 152-161.

${ }^{26}$ Ps 136 takes up the pattern of the historical creed, but refers to creation. The refrain sees in all acts of Yahweh an expression of His merciful faithfulness. H.J. Kraus, Psalmen 2 (BK XV/2), Neukirchen 1966, 899-963. 
The first conclusion to be drawn from the analysis of the psalm is that praising the history of Israel in its very beginnings and worshipping the creation of the world is one and the same, because Israel believes in Yahweh, who for him is both the Creator of the universe and the Lord of its history. The starting point for this reflection was, of course, the history of the chosen people. Israel like every individual and every nation - needed to become aware of its own existence, before concentrating its attention on its beginnings and in turn on the beginnings of the universe. It is obvious that these two beginnings do not belong to the same order. There is a ravine between the creation of the universe from nothingness, or more precisely in this context - from chaos, and the emergence of Israel liberated from Egypt at a specific historical moment. Yet it is precisely the awareness of Israel's own origins and, as a consequence, of creation that is included in the combination of these two orders. If Israel lives and acts it is because it has owed its existence to Yahweh for centuries, i.e. from the very beginning, the decisive moments and events. In short, Israel was created by God. Salvation and existence - this is the fruit of the consciousness that Israel expresses through this psalm in relation to its origins. In relation to the universe, Israel contains, in some form, the beginning of things that occur in the entire creative work; it is a matter of salvation. It is, of course, a work of God and therefore worthy of praise. It is not important that it derives from mythical images, i.e. from an approach to issues that contains nothing of science. It corresponds to that stage of culture of the ancient Middle East in which Israel lived and thought. The essence and originality of Israeli thought lies in the fact that images, order of things, basic beliefs, as well as cognition derived from the observation of phenomena are related exclusively to Yahweh. If Ps 136 puts at the forefront of the essential things the faith of Israel, he does so because Israel was the first to free itself from concepts of the world contrary to that faith.

This Psalm can also be treated as a fruit and the purest expression of Israel's faith, which seeks to free itself from mythical fatalism. Regardless of our cognitive abilities, it is certain that God Himself acted in the creation of the universe, as well as in the emergence of man and the nation of Israel. Therefore, God's work, God's creative work as His historical work, is a salvific work, and only as such (salvific) is a creative work ${ }^{27}$.

Ps 33 and 89 remind us of the greatness of Yahweh, His goodness and righteousness, mentioning creation on an equal footing with the choosing

27 Cf. P. Gilbert, Idea stworzenia w Starym Testamencie “Communio" 4 (1982), 46-57; cf. also H.J. Kraus, Psalmen 2, op. cit., 900-902. 
of Israel and David ${ }^{28}$. Psalm 74 mentions his triumph over the powers of chaos among the works of God's release of Israel ${ }^{29}$. Psalms 145 et seq. place greater emphasis on the providential work of Yahweh and on the help he brings to the poor than on the work of salvation of $\mathrm{God}^{30}$.

Two psalms in particular deserve attention: 8 and 104 that show points of contact with Genesis 1. In addition, Ps 104 is close to the hymn to the sun god Aton, ascribed to Pharaoh Amenofis IV ${ }^{31}$. Both represent a tradition of wisdom, and the relationship they demonstrate with the history of salvation comes down to the use of the name of Yahweh. Ps 8 places the Creator, the work created and the creation itself in the manner of Genesis 1 in appropriate relationships. Ps 104 is more interested in God's dominion over nature, than in the creation of the world. The panorama of the world inspires admiration in the psalmist, who praises the greatness of the Creator, His knowledge and kindness towards the creations that fill the earth ${ }^{32}$.

\section{Wisdom Literature}

The above observations apply also to wisdom texts that were probably written in the period after the captivity. Here we are thinking above all of the Book of Proverbs and Job. The Israeli sage praises the infinite majesty of God, who wanted to bring heaven and earth to existence and brought order and harmony. Contemplation of the cosmos sustains his enthusiasm, but the history of salvation never enters consciously into his meditation on the work of the Creator God. The cosmogonic theme in the tradition of wisdom is based directly on the testimony that the universe gives to Yahweh. It is primarily of a doxological nature. Some texts from the Book of Proverbs remind us that the works of creation testify to the existence of the Creator on whom they are totally dependent and

28 Psalm 33 is an alphabetical prayer that takes up the traditional motifs of the royal reign of Yahweh, His creative work, and the world in general. Ps 89 - ending with a lamentation begins with a hymn praising at the same time the covenant with David and the defeat of the sea. Ps 24 combines the tradition of creation with the liturgy of the royalty of the Yahweh.

29 Ps 74 is a lamentation that supposes the destruction of the Jerusalem temple.

30 Cf. Ps 121:2; 124:8; 134:3; 135:6 and others.

31 Cf. R. Martin-Achard, Approches des Psaumes, CTh 60 (1969), 70-85; R. Tournay, Le psaume VIII et la doctrine biblique du Nom, RB 78 (1971), 18-30. For Ps 104 cf. H.J. Kraus, Psalmen 2, op. cit., 706. Cf. also H.W. Jüngling, "Macht euch die Erde untertan” (Gen 1, 38), in: “Theologisches Jahrbuch 1985”, Leipzig 1985, 56-59.64-66.

32 Cf. H.J. Kraus, Theologie der Psalmen (BK XV/3), Neukirchen. 
over whom God extends his care ${ }^{33}$. Other texts again show the role of Wisdom in the creation of the world. Proverbs 8:22n emphasizes its previous existence in relation to the world and its presence in the formation of heaven and earth ${ }^{34}$. The whole cosmos bears the sign of its Creator and pays tribute to Him.

The theme of creation plays a decisive role in $\mathrm{Job}^{35}$. It appears especially in the passage that speaks of Yahweh's wisdom and intelligence, revealed during the cosmogonic struggle with the forces of nothingness (Job 26:5-14) ${ }^{36}$. The second text praises wisdom, which is inaccessible to man, and which only God has. The expression of this wisdom is the establishment and determination of the laws of the universe (Job 28:26nn $)^{37}$. Job's poem ends with a suggestive description of the power of the Creator God (Job 38-41). Job emphasises that God gives him a hearing that he is in front of his face and in this way he makes contact with the Creator. He realises, however, that there is no proportion between creation and Creator. It is no longer for Job to report the matter to God, but Yahweh himself will lead his case and fill it with questions that Job is unable to answer. In order to embarrass him, God somehow introduces the universe to the stage, showing all its components, reminds him of the laws and asks Job about his participation in the creation of the world and its organisation. The creation is the clearest proof of the distance that separates Yahweh from his interlocutor. This distance reveals the finiteness of man and the absolute sovereignty of God over the work of creation.

In order to strengthen his arguments, the author of the Book of Job introduces monstrous beings such as Behemoth, the hippopotamus, Leviathan and the crocodile (Job 40n), which appear in the last part of Yahweh's discourse and are supposed to convince Job of the unexplored nature of God's activity $^{38}$. A creation is not able to understand God's work, it is not able to grasp its meaning. This spectacle of nature - not the story of salvation - puts the reader

33 Cf. Proverbs 14:31; 17:5; 20:12:22.

34 Cf. Job 28:20ff.

35 Cf. S. Terrien, Job (CAT XIII), Neuchâtel 1963; G. Fohrer, Das Buch Hiob (KAT 16), Gütersloh 1963; J. Levêque, Job et son Dieu. Essai d'exégèse et de théologie biblique, 2 vol. (EJB), Paris 1970.

36 Cf. R. Tournay, L'ordre primitif des chapitres XXIV-XXVIII du livre de Job, RB 64 (1957), 321-334. The author suggests moving 24:18-25 after 27:23 and 25:2-26:4 after 26:5-14.

37 Cf. Proverbs 3:19f and 8:22f.

38 Cf. E. Ruprecht, Das Nilpferd im Hiobbuch. Beobachtungen zu der sogenannten zweiten Gottesrede, VT 21 (1971), 209-231; J.V. Kimier Wilson, A return to the problems of Behemoth and Leviathan, VT 25 (1975), 1-14; B. Couroyer, Qui est Béhémoth? Job, XL, 15-24, RB 82 (1076), 418-443; cf. W. Zimmerli, op. cit., 24-34. \$4. Jahwe, der Schöpfer und König. 
of the Book of Job before the impenetrable mystery of God and encourages him towards admiration and adoration. Creations bear witness to the uncontested power of the Yahweh; they reveal the wisdom and power of the God of Israel.

\section{Conclusion}

Let us gather our comments in the form of conclusions.

1. It is true that the concept of creation takes on theological focus in Israel quite late. The chosen nation was primarily interested in history and its relation to God, and then asked a question about the beginning of the world. Over time, as a result of historical events, it gradually developed a lesson on creation. Babylonian slavery played a decisive role in the theological reflection on creation. 2. The Old Testament texts testify that the statement "Yahweh has made heaven and earth" corresponds to a threefold theological intention. It has at the same time a doxological, soteriological and polemic character. The Old Testament taken as a whole evokes a cosmogonic fact to praise the glory of the God of Israel and emphasise His transcendence, to question the worship of nature, freeing man from the caring cosmic and agrarian forces, and to guarantee salvation for Israel and the world, relying on the power of God, able to make all things new out of love for his chosen.

3. The Old Testament shows us that the theological reflection on the creation of the world and mankind has been expressed in various forms in the history of Israel, there is no single formula of Israel's faith in creation, but it is always about the same faith expressed in a formulation conditioned by the current cultural context, always with the triple theological intentions mentioned above. This can be seen in the Old Testament writings, starting with the Jehovah and the priestly writer, through Deutero-Isaiah and the author of the Book of Job, whose faith was later expressed in the first article of the creed: "I believe in God the Almighty Father, the Creator of heaven and earth." 